\title{
Estimation of price and income elasticity of water: a case study of Darjeeling town, West Bengal, India
}

\author{
Debi Prasad Bal ${ }^{1, *}$, Ashish Chhetri ${ }^{2}$, Barun Kumar Thakur ${ }^{3}$ and Kanish Debnath ${ }^{3}$ \\ ${ }^{1}$ Department of Economics, Birla School of Social Sciences and Humanities, Birla Global University, Bhubaneswar 751029 , India \\ ${ }^{2}$ Department of Geography, University of Calcutta, Kolkata 700073 , India \\ ${ }^{3}$ FLAME University, Pune 412 115, India
}

This study examines the price and income elasticity of water of Darjeeling town in West Bengal, India. We collected the primary data between 2017 and 2018 through the survey method. Here simple random sampling has been used for interviewing 100 households. We divided the households into groups of 25 each according to the mode of consumption of water, such as domestic pipeline, commercial pipeline, domestic water tanker and commercial water tanker. This study concludes that the price for domestic pipeline connection, commercial pipeline, domestic water tanker and commercial water tanker is elastic by using the midpoint formulae of elasticity. More specifically, the consumption of water from commercial tankers and households that have commercial pipeline connection have relatively high elasticity as compared to households depending on domestic pipeline connection and domestic water tanker. Further, the result shows that the income elasticity of water demand is relatively high. Mainly, the income elasticity is less in households under domestic pipeline and domestic water tanker compared to those under commercial pipeline and commercial water tanker. The overall implication of the study is that rising water per litre price has compelled the residents to compromise on the quality of drinking water. Therefore, it is recommended that the government follows the objective of inter-generational equity for water in the long run.

Keywords: Pipeline connection, price and income elasticity, simple random sampling, water demand, water tanker.

\section{Introduction}

THE exponential rise in the price of water per litre in Darjeeling town, West Bengal, India has compelled the residents to compromise on both the quality and quantity of drinking water. The price of water keeps increasing at regular intervals owing to the monopoly market, where

*For correspondence. (e-mail: debiprasad.bal@gmail.com) there is no prescribed benchmark to fix the price of drinking water. Although the scarcity of drinking water is quite less in rainy seasons, in dry seasons, people have to depend on the water supplied by private vendors through water tankers and pipelines. Not only do the consumers have to pay different rates to collect water from the water tankers (depending on the distance covered by the tankers), but they also have to compromise the quality of water used for drinking and domestic purposes. The tankers collect the water from Jhoras (mountain springs) without any considerations about the quality of drinking water. Most water tanker operators seem to be more concerned about making profits and care less for the health of the customer. Therefore, we can stress that the water problem in Darjeeling that seems obvious is not only limited to the quantitative aspect, but also the qualitative aspect where drinking water quality parameters are grossly neglected. In such scenarios, consumers usually convey their dissatisfaction with the existing water supply through changes in demand. Therefore, in this study, we examine the sensitivity of consumers' drinking water demand to Darjeeling's prices and income.

Striking a perfect balance between water demand and supply has always been a pressing problem in the developing countries of the world. The impending water crisis is a necessary trait of almost every Himalayan town and cities which has to sustain over limited and constrained water sources. Darjeeling, a well-known Himalayan town, is often considered to be water scarce, and the water crisis in the region is symptomatic of a hydrological paradox ${ }^{1}$. Despite the abundant monsoon rainfall supplemented by several perennial rivers and streams, the town faces an acute water crisis, particularly during dry seasons ${ }^{2}$. The complicated hydro-geological settings and steep alignments of resistant rocks do not allow people to dig or construct borewells to extract groundwater in the region. The ridge-top location of the town again deprives it from accessing the surface water (rivers and streams), which flows constantly down the hills through the underlying valley floors. Hence, paradoxically, the people of this town depend profusely on spring water (groundwater) for their sustenance ${ }^{3}$. 
Like any other growing hill town, Darjeeling is witnessing a remarkable alteration in terms of expansion, growth, development, and other anthropogenic activities. Darjeeling faces many problems, such as shrinkage of internal spacing, rapid and unplanned urbanization, high population influx, inadequate water supply and sanitation, unscientific waste management system, air and noise pollution and uncollected refuse. All these have severely affected the pressing problem of water scarcity and water resource management, which has become a severe issue in the town. The outdated colonial public water supply system still exists in the town, which needs urgent repair, revitalization, and improvement ${ }^{2}$. Hence, the existing public water supply system has been unable to bridge the gap between water demand and supply in the town. The daily water requirement of the town is about $1,860,0000$ gallons, but the municipality supplies only about 527,5000 gallons of water, thereby inducing a water deficit of about $1,332,5000$ gallons per day ${ }^{4}$. The urban poor is traumatically vulnerable to severe water insecurity in the town as it progressively adapts to a profit-based private water supply system, which is highly costly. The stress of water scarcity is more among the poor who use water for domestic purposes than the rich who consume a considerable volume of water for domestic and commercial purposes. The growth of tourism industry, hotels and restaurant chains has resulted in the consumption of larger quantities of potable water as a commercial commodity. It exacerbates the situation of water inequality and water injustice among the poor in the town. This situation of injustice arising from the capture of significant water resources by a section of society is creating unfair competition for water accessibility among the poor. It generates more stress and a high dependency on the local natural springs.

Statistics shows that an increasing population has resulted in a reduction in per capita consumption of water every year in India ${ }^{5}$. Consequently, natural springs as a water source in Darjeeling provide about $70 \%$ of the total water requirement for drinking and domestic purposes for the sustenance of the common people. The random destruction of the natural environment, depletion of forests, and the rapid urbanization have considerably deteriorated the quality and discharging capacity of the existing springs. The demand for water has been estimated by the water resource economists since 1960s (refs 6,7). Particular attention has been given to measuring the price elasticity demand of water. The price elasticity of water states that the percentage of change in the quantity demand of the water varies due to the percentage change in the price of water. In this context, the present study measures the price as well as income elasticity of water for Darjeeling town.

The contribution of this study is as follows. Firstly, to our knowledge, it is the first study of its kind to examine the price and income elasticity of drinking water in the case of the Indian Himalayas in general and Darjeeling in particular. As far as consumer theory is concerned, it posits that the number of goods and services demanded will be inversely related to their prices and directly related to the income of the consumer. However, empirical investigations of drinking water demand in the case of India is uncommon. Secondly, this study also estimates the change in demand for over two years. Since the demand for water is increasing over the period due to the increasing level of population, increasing level of tourism, industrialization, climatic change, etc., it is vital to determine the extent to which the consumer's price and income influence the water demand. Our results are robust in the sense that we compare them with the panel regression model.

\section{Theoretical framework}

The quantity demand for water has been influenced by important factors such as population, price, consumer income, seasonality, natural factors, etc. ${ }^{8}$. Among these, price and income greatly influence the quantity demand of water ${ }^{8}$. Here the quantity demand function is assumed as continuous. So the percentage changes in quantity demand can be captured due to change in the price. The theoretical model can be established between the demand of water and its price can be present with consumer utility analysis. The utility function on water demand is

$\max u(x)$,

Subject to $p x \leq m$, where $p \succ 0$ and $m \geq 0$,

where $u(x)$ is for maximizing the consumer utility function for water, $p x$ is the price per unit of consuming $x$ units of goods and $m$ is the income of the consumers. From that utility, we try to examine the quantity demand for water with the constraint of price and income of the consumer. So, any increase (or decrease) in water price does have both income and substitution effects on the consumers. The income effects are due to either increase (or decrease) of water price, and this will have an increase (or decrease) in the purchasing power of the consumers. For the substitution effect, we know that there is nothing to substitute for water. However, if we consider the use of water for other purposes such as gardening, swimming pools, agricultural purposes, etc., there may have substitution effects. Further, we also assume that other things such as seasonality, taste and preferences, etc. remain constant. The main motive behind presenting the utility function is to establish the relationship between the quantity demand of water and the income of the consumer as well as the price of water.

Based on this theoretical model, we specify the water demand nexus as

$$
\mathrm{QD}=f(p, m),
$$


where QD is the quantity demand for water, $p$ the price of water and $m$ is the income. This a priori information suggests that the relationship between income of the consumer and quantity demand of the water is to be positive and there will be ambiguous effects between the price of water and its quantity demand ${ }^{9-13}$. In this case, we specify our model as follows

$$
\mathrm{QD}_{t}=\beta_{0}+\beta_{1} p_{t}+\beta_{2} m_{t}+\mu_{t},
$$

where $\beta_{1}$ is the intercept term and is the slope coefficient of price and $\beta_{2}$ the slope coefficient of income and $\mu_{t}$ is the error term.

\section{Literature review}

Most of the previous studies on water demand for different countries or regions suggest that price and income elasticities of water are generally inelastic, which varies between unity and less than unity. In this context, Conley ${ }^{9}$ estimated the price elasticity of the demand for water for agricultural, household and industrial purposes in southern California, USA. The study concluded that the price elasticity demand was highly inelastic for industrial purposes, whereas it was less inelastic for household and agricultural purposes. Schoengold et al. ${ }^{10}$ estimated the price elasticity of the irrigation water demand for San Joaquin Valley, California over the period 1994-2001. Mainly the study covered 150 farming operations located 90 miles north of Los Angeles in California. Using the panel data and panel regression method with instrumental variables, they conclude that the demand is more price elastic. Thomas and Syme ${ }^{11}$ examined the price elasticity of demand for public water supplies in Perth, Western Australia in 1981-82. They used the stratified random sample of 400 households and the contingent valuation method. They concluded that the price elasticity of demand was relatively less inelastic. Espey et al. ${ }^{7}$ estimated the price elasticity of residential water demand in the case of USA. Using the meta-analysis method, they found that the price of water, income, rainfall, and evaporation are the essential factors that influence the calculation of price elasticity.

In contrast, population density, household size and temperature are not statistically significant to determine for measuring the price elasticity. Dalhuisen et al. ${ }^{14}$ estimated the price and income elasticity for residential water demand and conclude that the elasticity is relatively priced elastic and income inelastic. Agthe and Billings ${ }^{15}$ examined the price elasticity in Tucson and Arizona, USA with increasing block rates for water using 45 monthly data from January 1974 to September 1977. They used the double logarithm and linear equation method and concluded that the demand of water is relatively less elastic. Nieswiadomy ${ }^{16}$ estimated the urban residential water demand for cities in the north central, northeast, south and west regions of USA. The study used three types of models, viz. a marginal price model, an average price model, and $\mathrm{Shin}^{17}$ price perception model, and the simultaneous equation framework. They conclude that price elasticity is higher in the cities of south and west than in the north-central and northeast regions of USA. Table 1 provides a brief review related to the water price elasticity in case of a household, agricultural, and industrial water demand.

\section{Data sources and methodology}

\section{Data sources}

This study is based on primary data gathered from personal interviews with the respondents (households). A survey has been conducted from January to December 2017 and 2018 respectively, in Darjeeling town. The primary data consist of socioeconomic characteristics of the households, dependency on water, and attitude on consumption of water for regular activity. In this study, a total of 100 households were interviewed for the collection of data. Simple random sampling was used for data collection and face-to-face interviews with the households were conducted. Our survey is based on a different mode of consumption of water, such as domestic pipeline connection, commercial pipeline for hotels and restaurants, domestic water tanker, and commercial water tanker. The questionnaire was to gather primary information such as socio-demographic profiles, the daily consumption of water, and the storage of water during dry, winter and rainy seasons. Figure 1 is a location map of the study area.

\section{Methodology}

We used the midpoint method to compute the price and income elasticity of water demand. The price elasticity of demand computes the percentage change of quantity demand with respect to the percentage change of its price. More specifically, it measures how much the quantity demand responds to a change in price. The demand is considered to be elastic when the quantity demand responds more to a small change in its price. On the other hand, the demand is considered to be inelastic when the quantity demand responds less to a small change in its price. So, the general formula to measure the elasticity of demand can be written as

$$
\left|\varepsilon_{\mathrm{p}}\right|=\frac{\Delta Q}{\Delta P} \cdot \frac{P}{Q}
$$

where $\varepsilon_{\mathrm{p}}$ is the price elasticity of demand, $\Delta Q$ the change of quantity demand for water, $\Delta P$ the change in water 
NATIONAL MISSION ON HIMALAYAN STUDIES

Table 1. Brief review of literature on the elasticity of demand for water

\begin{tabular}{|c|c|c|c|c|}
\hline Author (s) & Period of study & Study region & Methodology & Findings \\
\hline Young $^{8}$ & $1946-1964$ & $\begin{array}{l}\text { Tucson, Arizona, } \\
\text { USA }\end{array}$ & Regression model & Relatively price elastic demand \\
\hline $\mathrm{Camp}^{18}$ & $\begin{array}{l}\text { Primary data for } \\
288 \text { consumers, } \\
1971\end{array}$ & $\begin{array}{l}\text { North Mississippi, } \\
\text { USA }\end{array}$ & Regression method & $\begin{array}{l}\text { Relatively price elastic domestic water } \\
\text { demand. }\end{array}$ \\
\hline $\begin{array}{l}\text { Dharmaratna and } \\
\text { Harris }^{19}\end{array}$ & $2001-05$ & Sri Lanka & $\begin{array}{l}\text { The Stone-Geary } \\
\text { functional form } \\
\text { using both OLS } \\
\text { and panel corre- } \\
\text { lated standard } \\
\text { error technique }\end{array}$ & $\begin{array}{l}\text { Price insensitive to the consumption of } \\
\text { water. }\end{array}$ \\
\hline Dhungel and Fiedler ${ }^{20}$ & $2000-06$ & $\begin{array}{l}\text { Pullman, } \\
\text { Washington, } \\
\text { USA }\end{array}$ & Regression technique & Price inelastic water demand. \\
\hline Marzano et al. ${ }^{12}$ & $\begin{array}{l}\text { 1963-2013 } \\
\text { covering } 124 \\
\text { papers }\end{array}$ & $\begin{array}{l}52 \% \text { of the studies } \\
\text { are based in USA }\end{array}$ & $\begin{array}{l}\text { Meta-regression } \\
\text { analysis and } \\
\text { simulation. }\end{array}$ & $\begin{array}{l}\text { Estimated value of price elasticity is low, } \\
\text { indicating the relative price inelastic } \\
\text { water demand. Despite evidence of low } \\
\text { average price elasticity, the scenarios } \\
\text { simulated using meta-regression estimates } \\
\text { show that increasing block rate tariffs are } \\
\text { associated with higher price elasticity. }\end{array}$ \\
\hline $\begin{array}{l}\text { Metaxas and } \\
\text { Charalambous }^{13}\end{array}$ & $1992-2003$ & $\begin{array}{l}\text { Australia, Cyprus, } \\
\text { Denmark, Finland, } \\
\text { Italy and } \\
\text { The Netherlands }\end{array}$ & Elasticity formula & $\begin{array}{l}\text { Price elasticity of residential water is } \\
\text { inelastic. }\end{array}$ \\
\hline Ghimire et al. ${ }^{21}$ & $\begin{array}{l}\text { July 2009- } \\
\text { December } 2012\end{array}$ & USA & $\begin{array}{l}\text { Two-stage least } \\
\text { squares regression }\end{array}$ & $\begin{array}{l}\text { Water demand is inelastic to water price, } \\
\text { except for high consumption periods }\end{array}$ \\
\hline Hoyos and Artabe 22 & 2012 & Spain & Regression & Demand for water is inelastic \\
\hline Hung et al. ${ }^{23}$ & 2005 & Taiwan & $\begin{array}{l}\text { Stone-Geary utility } \\
\text { function and } \\
\text { stochastic frontier } \\
\text { approach }\end{array}$ & $\begin{array}{l}\text { Estimated price and income elasticities are } \\
\text { below } 0.1 \text { in absolute value }\end{array}$ \\
\hline Havranek et al. ${ }^{24}$ & $\begin{array}{l}\text { Multiple published } \\
\text { study }\end{array}$ & $\begin{array}{l}\text { Multiple published } \\
\text { study }\end{array}$ & Meta-analysis & $\begin{array}{l}\text { Price elasticity is approximately } 0.15 \text { or less } \\
\text { after controlling for more than } 30 \\
\text { characteristics of the estimates and } \\
\text { accounting for model uncertainty }\end{array}$ \\
\hline Garrone et al..$^{25}$ & $\begin{array}{l}\text { Multiple published } \\
\text { study }\end{array}$ & $\begin{array}{l}\text { Multiple published } \\
\text { study }\end{array}$ & $\begin{array}{l}\text { A meta-regression } \\
\text { that summarizes } \\
615 \text { estimates of } \\
\text { price elasticity of } \\
\text { residential water } \\
\text { demand }\end{array}$ & $\begin{array}{l}\text { Water scarcity is a significant driver of } \\
\text { price elasticity. When water scarcity } \\
\text { is harsh, residents' sensitivity to price } \\
\text { measures decreases. }\end{array}$ \\
\hline Gross and Elshiewy ${ }^{26}$ & 2010 & Benin & $\begin{array}{l}\text { A mixed conditional } \\
\text { multinomial logit } \\
\text { model }\end{array}$ & $\begin{array}{l}\text { Price only affects water quantity demand } \\
\text { from improved sources, while distance } \\
\text { only affects water quantity demand } \\
\text { from unimproved sources. }\end{array}$ \\
\hline $\begin{array}{l}\text { Schleich and } \\
\quad \text { Hillenbrand }^{27}\end{array}$ & $2007-13$ & Germany & Panel estimation & $\begin{array}{l}\text { The short-run (long-run) price elasticity is } \\
\text { estimated at around } 4.2 \%(13 \%) \text {, but } \\
\text { water demand appears to respond } \\
\text { asymmetrically to rising and falling } \\
\text { prices. }\end{array}$ \\
\hline
\end{tabular}

price, $P$ represents the original water price, and $Q$ is the original quantity demand for water. The absolute value of the elasticity of demand varies between 0 (perfect inelastic demand) and infinity (perfect elastic demand). If the calculated value is zero, then the demand for the goods and services is perfectly inelastic. The perfectly inelastic demand indicates that no substitute goods or services are available. Similarly, if the measured value is infinite, then it is a perfectly elastic demand indicating that a large number of substitute goods and services are available to the consumers. If we use the above formula to measure the elasticity from one point to another point and reverse, we may get two results. The reason is that the calculation is done with a different base. So, to avoid such problems, 


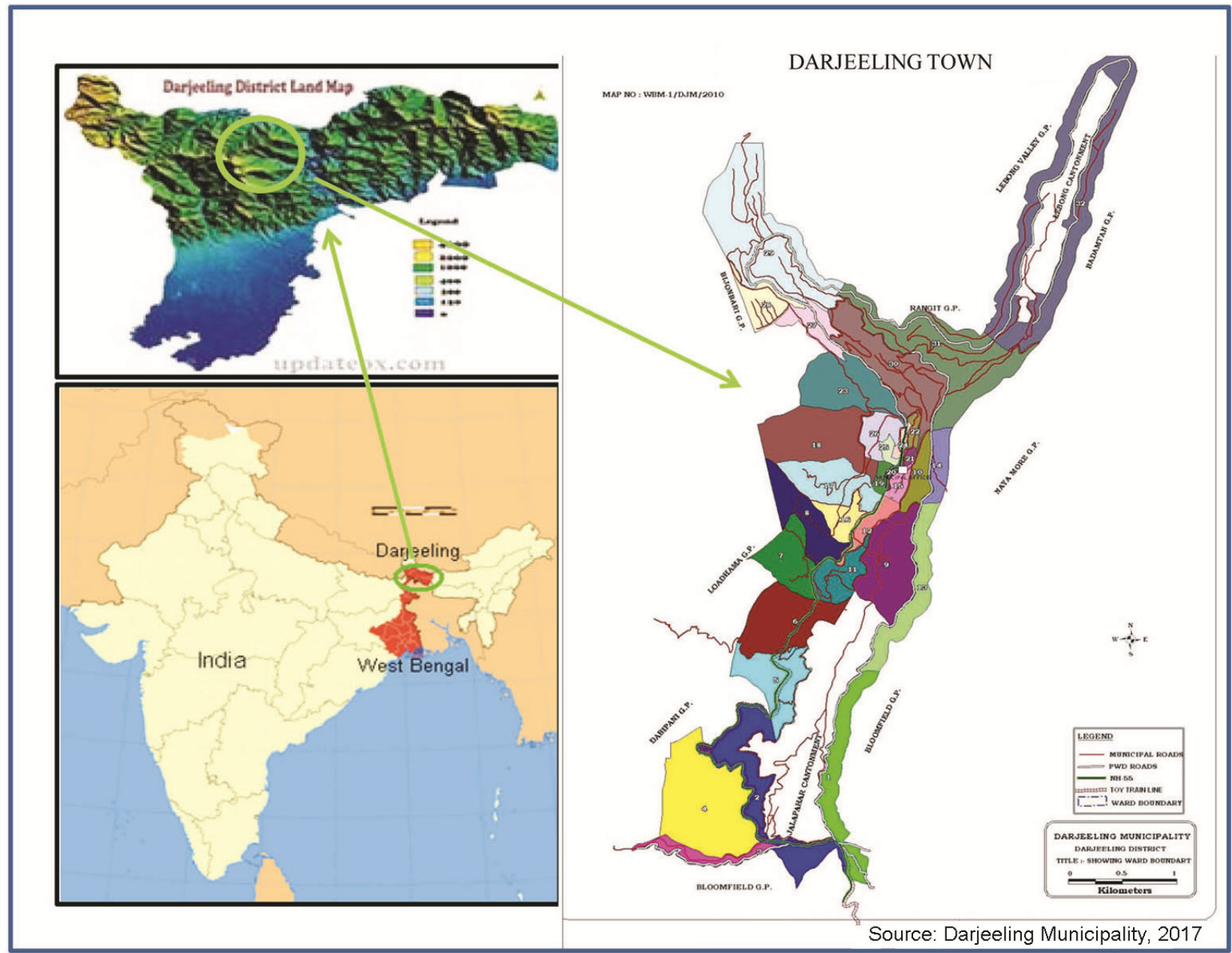

Figure 1. Location map of the study area.

we use the midpoint method to measure the elasticity as follows

$$
\left|\varepsilon_{\mathrm{p}}\right|=\frac{\left(Q_{2}-Q_{1}\right) /\left(Q_{2}-Q_{1}\right) / 2}{\left(P_{2}-P_{1}\right) /\left(P_{2}+P_{1}\right) / 2}
$$

where, $\varepsilon_{\mathrm{p}}$ shows price elasticity demand, $Q_{2}$ the quantity demand in the second period, $Q_{1}$ the quantity demand in the first period, $P_{2}$ the price of the second period, and $P_{1}$ is the price of the first period.

\section{Panel regression model}

We used the two-period panel regression models for the robustness of the results. It is as follows.

We used two-period panel regression models in our analysis; that is, the year 2017 and 2018. It allows us to analyse the dynamic change of price and income on its quantity demand from 2017 to 2018 . In the first step, we considered the regression model as follows

$$
\begin{aligned}
& \mathrm{QD}_{i 2017}=\beta_{0}+\beta_{1} \mathrm{DPPW}_{i 2017}+\beta_{2} \mathrm{DPY}_{i 2017}+\mu_{i t} \\
& \mathrm{QD}_{i 2018}=\beta_{3}+\beta_{4} \mathrm{DPPW}_{i 2018}+\beta_{5} \mathrm{DPY}_{i 2018}+\mu_{i t} .
\end{aligned}
$$

In the next step, we have taken the difference of the period 2017 and 2018 and the regression model as follows

$$
\mathrm{QD}_{i 2017}-\mathrm{QD}_{i 2018}=\alpha+\beta_{1} \mathrm{DPPW}_{\mathrm{it}}+\beta_{2} \mathrm{DPY}_{\mathrm{it}}+v_{i t} \text {. }
$$

\section{Analysis of results}

A range of commonly used summary statistics for the variables is presented in Tables 2 and 3 for 2017 and 2018 respectively. The results illustrate that the average price of the domestic pipeline connection to the household was Rs 14.72 per 100 litre in 2017 and Rs 15.72 per 100 litre in 2018 respectively. The quantity demands are 5,520 and 5,820 litre respectively. The maximum and minimum price for water is Rs 23 and Rs 10 in the year 
Table 2. Descriptive statistics of price of water per 100 litre, monthly water demand and Income of households for 2017

\begin{tabular}{|c|c|c|c|c|c|c|c|}
\hline Variables & Mean & Maximum & Minimum & SD & Skewness & Kurtosis & JB \\
\hline $\mathrm{DPPW}_{\text {it }}$ & 14.72 & 23 & 10 & 4.03 & 0.43 & 1.98 & $1.87(0.39)$ \\
\hline $\mathrm{DPQD}_{\text {it }}$ & 5520 & 9500 & 3000 & 1888.78 & 0.26 & 2.27 & $0.83(0.65)$ \\
\hline TR1 & $81,254.4$ & 2185.00 & 300.00 & - & - & - & - \\
\hline $\mathrm{DPY}_{\mathrm{it}}$ & 25,832 & 52,000 & 12000 & 10098.34 & 0.87 & 2.98 & $3.21(0.20)$ \\
\hline $\mathrm{DCPW}_{\mathrm{it}}$ & 32.28 & 53 & 23 & 8.71 & 0.71 & 2.69 & $2.20(0.33)$ \\
\hline $\mathrm{DCQD}_{\mathrm{it}}$ & 43,080 & 85,000 & 15,000 & 18151 & 0.52 & 2.97 & $1.14(0.56)$ \\
\hline TR2 & $13,906.224$ & $45,050.00$ & 3450.00 & - & - & - & - \\
\hline $\mathrm{DCY}_{\text {it }}$ & 170,280 & 316,000 & 90,000 & $60,179.95$ & 0.70 & 2.59 & $2.24(0.32)$ \\
\hline DWPW $_{\text {it }}$ & 39.56 & 56 & 30 & 8.43 & 0.46 & 2.00 & $1.92(0.38)$ \\
\hline DWOD $_{\text {it }}$ & 3152 & 5600 & 1400 & 1341.67 & 0.34 & 1.87 & $1.82(0.40)$ \\
\hline TR3 & 1246.9312 & 3136.00 & 420.00 & - & - & - & - \\
\hline $\mathrm{DWY}_{\mathrm{it}}$ & 23428 & 42000 & 12,000 & 8067.19 & 0.82 & 2.92 & $2.79(0.24)$ \\
\hline $\mathrm{CWPW}_{\mathrm{it}}$ & 48.36 & 72 & 31 & 11.91 & 0.50 & 2.16 & $1.78(0.41)$ \\
\hline $\mathrm{CWQD}_{\text {it }}$ & 31,840 & 54,000 & 11,000 & 12766.1 & 0.01 & 1.93 & $1.18(0.55)$ \\
\hline TR4 & $15,397.824$ & $38,880.00$ & 3410.00 & - & - & - & - \\
\hline $\mathrm{CWY}_{\mathrm{it}}$ & 18,3040 & 320,000 & 100,000 & $61,216.47$ & 0.49 & 2.21 & $1.68(0.43)$ \\
\hline No. of households & 100 & 100 & 100 & 100 & 100 & 100 & 100 \\
\hline
\end{tabular}

Source: Authors' own calculations. Note: DPPW $\mathrm{it}_{\mathrm{it}} \mathrm{DCPW}_{\mathrm{it}}, \mathrm{DWPW}_{\mathrm{it}}, \mathrm{CWPW}_{\mathrm{it}}$ indicate the domestic pipeline, commercial pipeline, domestic water tanker and commercial water tanker prices for water respectively. DPQD $\mathrm{i}_{\mathrm{it}}, \mathrm{DCQD}_{\mathrm{it}}, \mathrm{DWQD}_{\mathrm{it}}$ and $\mathrm{CWQD}_{\mathrm{it}}$ indicate quantity demand of the domestic pipeline, commercial piple, domestic water tanker and commercial water tankers respectively. TR1, TR2, TR3, and TR4 indicate the total revenue of domestic pipeline, commercial piple, domestic water tanker and commercial water tankers respectively. DPY $\mathrm{it}_{\mathrm{it}}, \mathrm{DCY}_{\mathrm{it}}, \mathrm{DWY}_{\mathrm{it}}$ and $\mathrm{CW}_{\mathrm{it}}$ show the income of households that consume from the domestic pipeline, commercial pipeline, domestic water tanker, and commercial water tanker sources respectively.

2017 and 2018 respectively. Likewise, the average price of commercial pipeline connections, domestic water tankers, and commercial water tankers was Rs 32.28, Rs 39.56 and Rs 48.36 respectively, in 2017 and Rs 33.36, Rs 40.32, and Rs 49.96 respectively in 2018. The average quantity demand for consumption of water for the commercial pipeline, domestic water tanker, and commercial water tanker was 43,080, 3,153, and 31,840 1 in 2017 and $47,880,3,252$, and 35,9201 respectively, in 2018 . So, the total monthly revenue collected from the domestic pipeline, commercial pipeline, domestic water tanker, and commercial water tanker is Rs $81,254.40$, Rs $13,906.22$, Rs 1,246.93, and Rs 15,397.82 respectively in 2017 and Rs 914.90, Rs 159,727.68, Rs 1,311.21 and Rs 17,945.63 respectively in 2018 .

Thus, in total, the revenue collected monthly by the private water supplier from 100 households of all four water sources is Rs 111,805.38 in 2017 and Rs $179,899.42$ in 2018. More specifically, the random sample of 100 households of Darjeeling town spends per annum Rs 1,341,664.55 and Rs 2,158,793.07 for 2017 and 2018 respectively. On the contrary, the municipality charges only Rs 500 per annum per household. This gap indicates that inequality between water demand and its price in Darjeeling.

Similarly, the descriptive statistics such as median, standard deviation, skewness, kurtosis, and Jarque-Bera tests are presented in Tables 2 and 3 for the years 2017 and 2018 respectively. In this context, we examine the price as well as income elasticity for the consumption of water. These are calculated considering the households' average price income $e^{6,16,18}$. Thus, the study takes the average price and income of 100 households concerning average water consumption for both 2017 and 2018 . Table 4 presents the results. It can be seen that the results show that the consumption of water from the domestic pipeline, commercial pipeline, domestic water tanker and the commercial water tanker is price elastic.

More specifically, those persons who are dependent on the commercial water tanker and commercial pipeline connection is relatively highly elastic as compared to the domestic pipeline and domestic water tanker for the consumption of water. It indicates that a small change in price brings about a relatively significant change in the consumption of water. The possible reason could be that water demand remains the same irrespective of price; so to cope with this price rise, residents have to either depend on rainwater or fetch water from nearby public springs.

The residents practice rainwater harvesting and use rainwater for domestic purposes, including washing, cleaning, bathing, etc. However, due to the price rise, they are using rainwater for drinking purposes as well. They collect the rainwater through the fitted pipelines, which are connected with a tin roof and boil it before drinking. This is possible only for those living in their own houses with a structured tin roof. Individuals who are staying on rent, or those who do not have a structured tin roof complement the price rise by collecting water from nearby public springs. They have to collect water in the queue and use it for drinking as well as other purposes. In the next step, we calculate the income elasticity of water. The results show that the consumption of water is more elastic of income. More specifically, the income 
SPECIAL SECTION:

Table 3. Descriptive statistics of price of water per 100 litre, monthly water demand and income of households for 2018

\begin{tabular}{|c|c|c|c|c|c|c|c|}
\hline Variables & Mean & Maximum & Minimum & SD & Sk & $\mathrm{Ku}$ & JB \\
\hline $\mathrm{DPPW}_{\text {it }}$ & 15.72 & 23 & 10 & 4.76 & 0.24 & 1.54 & $2.44(0.29)$ \\
\hline DPOD $_{\text {it }}$ & 5820 & 11,000 & 3000 & 2197.91 & 0.40 & 2.48 & $0.95(0.62)$ \\
\hline TR1 & 914.904 & 2530.00 & 300.00 & - & - & - & - \\
\hline $\mathrm{DPY}_{\mathrm{it}}$ & 26680 & 55000 & 13000 & 10503.85 & 0.99 & 3.31 & $4.21(0.12)$ \\
\hline DCPW $_{\text {it }}$ & 33.36 & 55 & 23 & 9.50 & 0.77 & 2.70 & $2.56(0.27)$ \\
\hline $\mathrm{DCQD}_{\mathrm{it}}$ & 47,880 & 90,000 & 15,000 & 21793 & 0.26 & 2.02 & $1.28(0.52)$ \\
\hline TR2 & $159,727.68$ & $49,500.00$ & 3450.00 & - & - & - & - \\
\hline $\mathrm{DCY}_{\mathrm{it}}$ & 173,000 & 316,000 & 90,000 & $61,103.06$ & 0.63 & 2.42 & $2.04(0.36)$ \\
\hline DWPW $_{\text {it }}$ & 40.32 & 57 & 30 & 9.26 & 0.49 & 2.01 & $2.05(0.35)$ \\
\hline DWQD $_{\text {it }}$ & 3252 & 6000 & 1500 & 1448.59 & 0.46 & 1.98 & $1.95(0.37)$ \\
\hline TR3 & 1311.2064 & 3420.00 & 450.00 & - & - & - & - \\
\hline $\mathrm{DWY}_{\mathrm{it}}$ & 23,960 & 42,000 & 12,000 & 7881.83 & 0.83 & 3.06 & $2.89(0.23)$ \\
\hline $\mathrm{CWPW}_{\mathrm{it}}$ & 49.96 & 76 & 31 & 13.31 & 0.43 & 1.95 & $1.91(0.38)$ \\
\hline $\mathrm{CWQD}_{\mathrm{it}}$ & 35,920 & 74,000 & 11,000 & 16380.68 & 0.44 & 2.56 & $1.00(0.60)$ \\
\hline TR4 & $17,945.632$ & $56,240.00$ & 3410.00 & - & - & - & - \\
\hline $\mathrm{CWY}_{\mathrm{it}}$ & 195,200 & 320,000 & 100,000 & $63,516.40$ & 0.26 & 1.92 & $1.49(0.47)$ \\
\hline No. of households & 100 & 100 & 100 & 100 & 100 & 100 & 100 \\
\hline
\end{tabular}

Source: Authors' own calculation.

Table 4. Measurement of price and income elasticities from midpoint formula between the years 2017 and 2018

\begin{tabular}{lc}
\hline Domestic pipeline & \\
Price elasticity & -0.80529 \\
Income elasticity & 1.6385 \\
Commercial pipelines & \\
Price elasticity & -3.20727 \\
Income elasticity & 6.6599 \\
Domestic water tanker & \\
Price elasticity & -1.64124 \\
Income elasticity & 1.3910 \\
Commercial water tanker & \\
Price elasticity & -3.70005 \\
Income elasticity & 1.8731 \\
\hline
\end{tabular}

Source: Authors' own calculations.

elasticity is less in the domestic pipeline and domestic water tanker-dependent households compared to the commercial pipeline and commercial water tankerdependent households.

Further, we used the panel regression method in order to test the robustness of our results. We found similar kind of results obtained from the midpoint formula. Table 5 shows the price and income elasticities of water. The dependant variable is the quantity demand per 1001 of the domestic pipeline, commercial pipeline, domestic water tanker, and commercial water tankers respectively. It shows that the price is relatively inelastic. This implies that one percentage increase in price of water leads to a reduction of about $0.45 \%$ of the consumption of water.

Similarly, every one percent change of price for commercial pipeline leads to a decline of $0.26 \%$ of quantity demand. This indicates that the demand for water is relatively inelastic for those who are dependent on domestic and commercial pipeline people. Along the same line, the results show that the income elasticity is relatively less elastic for commercial pipeline than domestic pipeline connection. More specifically, a one percent change in income leads to 0.37 and $0.68 \%$ increase in quantity demand of domestic pipeline and commercial pipeline, respectively.

The results of domestic and commercial water tankerdependent households show that the relationship between price and quantity demand does not satisfy the law of demand, i.e. we find that $1 \%$ change of price results in $0.59 \%$ and $0.19 \%$ increase in the quantity demand of domestic and commercial water tankers respectively. It is because there is no substitute for water. It is a necessary consumption for everyone. Therefore, the increasing price of water does not affect the level of consumption. Similarly, the income elasticity is relatively more elastic for commercial water tankers compared to domestic water tanker.

\section{Residual diagnostic test}

We checked the residual diagnostic, and the results are given in Table 5. The R-square shows the coefficient of determination and F-statistics, which shows the overall significance of the model. The results of $r$-square from the three models suggest that overall the model is perfectly fit. More particularly, the explanatory variable explains nicely about the dependent variable. Further, the F-value of all the models is significant, which indicates that overall the models are significant. It indicates the existence of a significant long-run relationship between the variables.

\section{Conclusion}

This study has analysed the price and income elasticities for water demand in Darjeeling. We conducted a primary 
Table 5. Results of price and income elasticity from panel regression method

\begin{tabular}{|c|c|}
\hline \multicolumn{2}{|c|}{ Domestic pipeline } \\
\hline \multicolumn{2}{|c|}{ Dependent variable - DPQD $D_{i t}$} \\
\hline $\mathrm{DPPW}_{\text {it }}$ & $-0.45(0.00)$ \\
\hline $\mathrm{DPY}_{\text {it }}$ & $0.37(0.00)$ \\
\hline Constant & $8.21(0.00)$ \\
\hline$R^{2}$ & 0.87 \\
\hline$F$ statistics & $159.95(0.00)$ \\
\hline \multicolumn{2}{|c|}{ Commercial pipeline } \\
\hline \multicolumn{2}{|c|}{ Dependent variable - DCQD ${ }_{\text {it }}$} \\
\hline $\mathrm{DCPW}_{\mathrm{it}}$ & $-0.26(0.02)$ \\
\hline $\mathrm{DCY}_{\mathrm{it}}$ & $0.68(0.00)$ \\
\hline Constant & $3.34(0.03)$ \\
\hline$R^{2}$ & 0.61 \\
\hline$F$ statistics & $36.19(0.00)$ \\
\hline \multicolumn{2}{|c|}{ Domestic water tanker } \\
\hline \multicolumn{2}{|c|}{ Dependent variable - DWQD $_{\text {it }}$} \\
\hline $\mathrm{DWPD}_{\text {it }}$ & $0.59(0.00)$ \\
\hline $\mathrm{DWY}_{\mathrm{it}}$ & $0.24(0.00)$ \\
\hline Constant & $3.41(0.00)$ \\
\hline$R^{2}$ & 0.66 \\
\hline$F$ statistics & $44.86(0.00)$ \\
\hline \multicolumn{2}{|c|}{ Commercial water tanker } \\
\hline \multicolumn{2}{|c|}{ Dependent variable $-\mathrm{CWQD}_{\mathrm{it}}$} \\
\hline $\mathrm{CWPW}_{\mathrm{it}}$ & $0.19(0.04)$ \\
\hline $\mathrm{CWY}_{\text {it }}$ & $0.42(0.00)$ \\
\hline Constant & $4.46(0.00)$ \\
\hline$R^{2}$ & 0.33 \\
\hline$F$ statistics & $11.56(0.00)$ \\
\hline
\end{tabular}

Source: Authors' own calculations. Figures in parenthesis are $P$-values.

survey in 2017 and 2018. The results from descriptive statistics show that the demand for commercial water tankers is higher than that of other modes of water consumption. Next, we measure the price and income elasticities of all modes of water consumption. We concluded that the consumption of water for commercial (water tanker and pipeline) purposes is relatively high elastic as compared to the domestic (water tanker and pipeline) usage. It indicates that the use of domestic water consumption is mainly price-driven. This means that if the government can provide subsidized water for domestic purpose, then the utility of water can be maximized.

Similarly, the result shows that income is less elastic in domestic water users. It indicates that income is one of the crucial factors which is pulling down to consume more water and being forced to rely on the use of the same water for less important usage. The literature, such as Metaxas and Charalambous ${ }^{13}$, Marzano et al. ${ }^{12}$ and Dhungel and Fiedler ${ }^{20}$ concluded a similar kind of results. Hence, our results are robust and have suitable policy implications. Taking the hygienic and health factors into consideration, the utility function for water can be maximized if the government can provide some alternative means of income, which can improve their income levels. Also, in order to fight COVID-19 recently, the government has to provide qualitative and sufficient water, which is the basic need of human beings. From a policy perspective, this study suggests that the municipality must try to minimize the dependency of water on private vendors through proper management of water supply. Further, outdated colonial public water supply systems still exist in the town, which need urgent repair, revitalization, and improvement.

1. Josi, D., Feminist solidarity? Women, water, and politics in the Darjeeling Himalaya. Mt. Res. Dev., 2014, 34, 243-255.

2. Drew, G. and Rai, R. P., Water management in post-colonial Darjeeling: The promise and limits of decentralised resource provision. Asian Stud. Rev., 2016, 40, 321-339.

3. Tambe, S., Kharel, G., Arrawatia, M. L., Kulkarni, H., Mahamuni, K. and Ganeriwala, A., Reviving dying springs: climate change adaptation experiments from the Sikkim Himalaya. Mt. Res. Dev., 2012, 32, 62-72.

4. Department of Information Technology, Annual Report. Government of Sikkim, 2012.

5. Shashikumar, K. C., Practical steps needed for water resource management. Curr. Sci., 2005, 88, 1714-1715.

6. Howe, C. W. and Linaweaver, F. P., The impact of price on residential water demand and its relation to system design and price structure. Water Resour. Res., 1967, 3, 13-32.

7. Espey, M., Espey, J., and Shaw, W. D., Price elasticity of residential demand for water: a meta-analysis. Water Resour. Res., 1997, 33, 1369-1374.

8. Young, R. A., Price elasticity of demand for municipal water: A case study of Tucson, Arizona. Water Resour. Res, 1973, 9, 10681072.

9. Conley, B. C., Price elasticity of the demand for water in Southern California. Ann. Reg. Sci., 1967, 1, 180-189. 
SPECIAL SECTION:

10. Schoengold, K., Sunding, D. L. and Moreno, G., Price elasticity reconsidered: Panel estimation of an agricultural water demand function. Water Resour. Res., 2006, 42, W09411.

11. Thomas, J. F. and Syme, G. J., Estimating residential price elasticity of demand for water: A contingent valuation approach. Water Resour. Res., 1988, 24, 1847-1857.

12. Marzano, R., Rougé, C., Garrone, P., Grilli, L., Harou, J. J. and Pulido-Velazquez, M., Determinants of the price response to residential water tariffs: meta-analysis and beyond. Environ. Modell. Softw., 2018, 101, 236-248.

13. Metaxas, S. and Charalambous, E., Residential price elasticity of demand for water. Water Supply, 2005, 5, 183-188.

14. Dalhuisen, J. M., Florax, R. J. G. M., de Groot, H. L. F., and Nijkamp, P., Price and income elasticities of residential water demand: a meta-analysis. Land Econ., 2003, 79, 292-308.

15. Agthe, D. E. and Billings, R. B., Dynamic models of residential water demand. Water Resour. Res., 1980, 16, 476-480.

16. Nieswiadomy, M. L., Estimating urban residential water demand: Effects of price structure, conservation, and education. Water Resour. Res., 1992, 28, 609-615.

17. Shin, J.-S., Perception of price when price information is costly: evidence from residential electricity demand. Rev. Econ. Statist., 1985, 67, 591 .

18. Camp, R. C., The Inelastic Demand for Residential Water: New Findings. J. Am. Water Works Assoc., 1978, 70, 453-458.

19. Dharmaratna, D. and Harris, E., Estimating residential water demand using the Stone-Geary functional form: the case of Sri Lanka. Water Resour. Manage., 2012, 26, 2283-2299.

20. Dhungel, R. and Fiedler, F., Price elasticity of water demand in a small college town: an inclusion of system dynamics approach for water demand forecast. Air, Soil Water Res., 2014, 7, ASWR.S15395.

21. Ghimire, M., Boyer, T. A., Chung, C. and Moss, J. Q., Estimation of residential water demand under uniform volumetric water pricing. J. Water Resour. Plann. Manage., 2016, 142, 04015054.

22. Hoyos, D. and Artabe, A., Regional differences in the price elasticity of residential water demand in Spain. Water Resour. Manage., 2017, 31, 847-865.

23. Hung, M.-F., Chie, B.-T. and Huang, T.-H., Residential water demand and water waste in Taiwan. Environ. Econ. Policy Stud., 2017, 19, 249-268.

24. Havranek, T., Irsova, Z., and Vlach, T., Measuring the income elasticity of water demand: the importance of publication and endogeneity biases. Land Econ., 2018, 94, 259-283.

25. Garrone, P., Grilli, L. and Marzano, R., Price elasticity of water demand considering scarcity and attitudes. Utilities Policy, 2019, 59, 100927.

26. Gross, E. and Elshiewy, O., Choice and quantity demand for improved and unimproved public water sources in rural areas: Evidence from Benin. J. Rural Stud., 2019, 69, 186-194.

27. Schleich, J. and Hillenbrand, T., Residential water demand responds asymmetrically to rising and falling prices. Appl. Econ., 2019, 51, 4973-4981.

ACKNOWLEDGEMENTS. We thank the National Mission on Himalaya Studies, Ministry of Environment, Forest and Climate Change, Government of India, for providing financial support. We also thank Bhaskar Chettrri (Darjeeling) for providing useful suggestions.

doi: $10.18520 / \mathrm{cs} / \mathrm{v} 120 / \mathrm{i} 5 / 800-808$ 